\title{
USTVARJANJE PRODUKTIVNEGA GEOGRAFSKEGA UČNEGA OKOLJA Z VIDKA UČNIH STILOV, OBLIK IN METOD
}

\author{
Lea Nemec \\ Lokavec 48/b, SI-5270 Ajdovščina, Slovenija. \\ e-mail: leanemec@gmail.com
}

Izvirni znanstveni članek

COBISS 1.01

\section{Izvleček}

Izkušnje, ki jih pridobimo v prostoru (ne)posredno vplivajo na proces izobraževanja oz. na samo učno okolje. Prav zato je najbolj produktivno tisto učno okolje, ki temelji na izkustvenem učenju. $V$ tej raziskavi je izkušnja prevzela vodilno mesto pri oblikovanju didaktičnih pristopov k poučevanju geografije in opredeljevanju učnih stilov, oblik in metod oz. k ustvarjanju reprezentativnega geografskega učnega okolja.

Ključne besede: geografsko izobraževanje, prostor, učno okolje, učni stili, izkustveno učenje, učne oblike, učne metode.

\section{CREATING THE PRODUCTIVE GEOGRAPHICAL LEARNING ENVIRONMENT FROM THE POINT OF VIEW OF LEARNING- STYLES AND LEARNING-METHODS}

\begin{abstract}
Experiences, which we receive in space(in)directly influence on education process respectively on learning-environment. Because of that is the most productive learning-environment those witch founded on experiential-learning. In this research experience took the leading place in forming didactical approaches in teaching geography and to define learning-styles and methods respectively in the direction of creating representative geographical learningenvironment.
\end{abstract}

Key words: geographical education, space, learning-environment, learning-styles, experiential-learning, learning methods. 


\section{UVOD}

Številni so poskusi, s katerimi želimo definirati koncept prostora. Tako je prostor temeljni izraz človekove vključenosti v svet. Prostor je vedno dajanje reference, in prostori so bolj ali manj referenčne točke v projekciji nekoga, saj je prostor produkt izkušnje. Prostor označuje oboje, tako družbeno kot osebno izkušnjo (Zlatkovski 2005). Na ta način izkušnje, ki jih pridobimo v prostoru (ne)posredno vplivajo na sam proces izobraževanja, ki je neke vrste koprodukcija med učnim okoljem in učencem (Ehlers 2007). Slednji je osrednji člen učnega procesa, na katerega deluje samo okolje. Učno okolje pa je oblikovano iz fizičnega, virtualnega in multimedijskega ter telematskega prostora (Medmrežje 1), ki je oblikovano za aktivni učni proces ter za povečanje in podporo učenčevih možnosti za učenje. Reprezentativno učno okolje nudi različne delovne metode, možnosti medsebojnega vplivanja in dialoga ter smernice in podporo učencem (Medmrežje 1). Učno okolje pravzaprav predstavlja skupnost učencev, kjer skupno učenje in kultura lahko postaneta resničnost. Najbolj funkcionalno je tisto učno okolje, ki temelji na izkustvenem in problemsko zasnovanem učenju (Medmrežje 1). Končni produkt izobraževanja je znanje. Razumevanje vsebin na lokalni in globalni ravni omogoča zavedanje medsebojnih povezav. Sposobnost razumevanja stvari iz različnih zornih kotov je ključnega pomena za intranacionalno in internacionalno razumevanje kot osnove za ustvarjanje možnosti sodelovanja, ki podpirajo trajnostni razvoj (Resnik Planinc 2006 , 10). Le tega pa lahko doseže le ustrezno izobraženo prebivalstvo, ki je bolj dojemljivo za širše družbene probleme (Smrekar, 2006).

Slika 1: Povezava med življenjskim prostorom in procesom izobraževanja.

Picture 1: Connection between living space and education process.

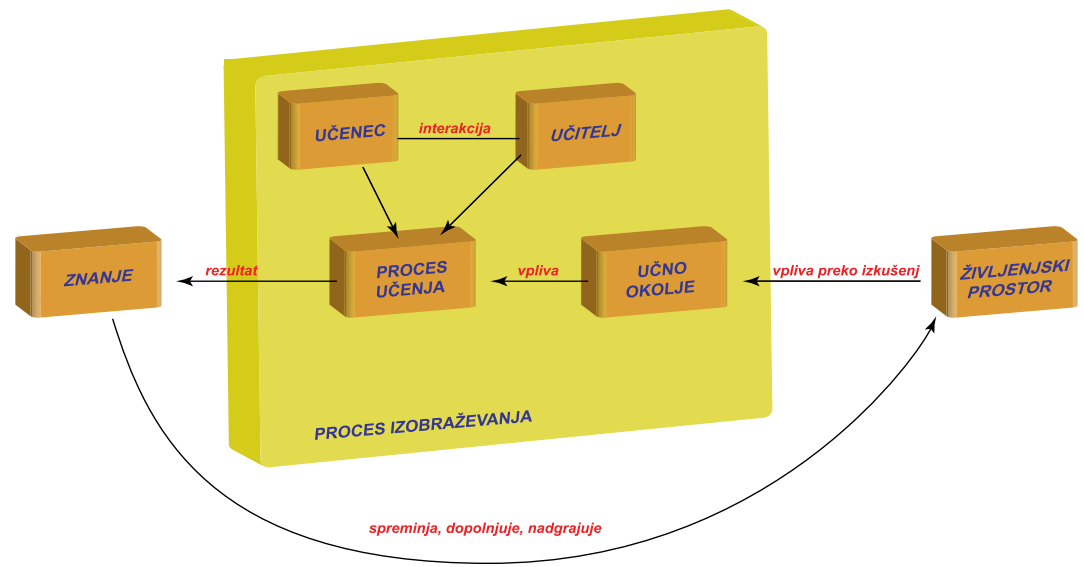

Današnje poučevanje največkrat posreduje snov na abstraktnem nivoju, v obliki teorij, zakonitosti in pojmov, v pričakovanju, da jo bodo učenci že kdaj pozneje uporabili v svojem življenju ali poklicnem delovanju (Resnik Planinc 2001, 89). Vendar tak način poučevanja, brez integracije med abstraktno konceptualizacijo in konkretno izkušnjo, učne snovi geo- 
grafije ne transformira v trajno novo znanje, temveč le začasno. Do trajnih spoznanj pridemo, če izkušnjam damo osrednjo vlogo v procesu učenja. Spoznali smo, da izkušnje pridobivamo iz prostora, v katerem živimo. Okolje, bolj natančno Zemljino površje, pa je predmet preučevanja geografije. Nakazana povezava nam torej prikazuje tesen preplet izkustvenega učenja in geografije. Prav zato je v tej raziskavi izkušnja prevzela vodilno mesto pri oblikovanju didaktičnih pristopov k poučevanju geografije in opredeljevanju učnih stilov, oblik in metod oz. k ustvarjanju produktivnega geografskega učnega okolja.

\section{UČNI STILI IN IZKUSTVENO UČENJE}

Načine pridobivanja informacij, konceptov in spretnosti imenujemo učni stil. »Učni stil je za posameznika značilna kombinacija učnih strategij (specifična kombinacija mentalnih operacij, ki jih nekdo uporablja glede na zahteve konkretne učne situacije/naloge), ki jih običajno uporablja v večini situacij. V učni stil poleg kombinacije strategij vključujemo tudi čustveno-motivacijske sestavine (cilji, namere v zvezi z učenjem) in pojmovanja o učenju (mentalni model učenja)« (Marentič-Požarnik 1995, 76). Učni stil torej tvori zbirka učnih strategij, ki predstavljajo zaporedje uporabljenih operacij pri učenju, npr. nekega teksta. Kakšen učenec bi se učenja tega teksta npr. lotil tako, da bi ga preletel, si izpisal glavne točke ter jih nato začel povezovati med seboj. Drug učenec bi se učenja istega teksta lotil s podrobnim branjem in podčrtovanjem ter takojšnjim natančnim memoriranjem. To so učne strategije, ki s svojimi kombinacijami zaznamujejo učne stile.

David Kolb je zgradil model učnih stilov na svojem pojmovanju procesa izkustvenega učenja. Učenje je po njegovem cikličen proces, $v$ katerem se stalno rešuje dialektično nasprotje oziroma napetost med dvema dimenzijama spoznavanja: dojemanja ter razumevanja na eni strani ter aktivnega delovanja in notranjega razmišljajočega opazovanja na drugi strani (Kolb 1984, 25).

Potencial izkustvenega učenja je torej v obravnavanju kompleksnih problemov skozi izkušnjo. Če izhajamo iz Vrišerjeve definicije geografije: »Geografija je veda o Zemljinem površju ali točno rečeno o Zemljini površinski sferi. Ugotavljala naj bi razširjenost, vplive in medsebojno soodvisnost tistih prirodnih in družbenih pojavov oziroma faktorjev, ki sodelujejo pri oblikovanju Zemljine površinske sfere kot celote ali njenih prostorskih delov« (Vrišer 1998, 5), bi lahko dejali, da je geografija vse, kar se dogaja okoli nas.

Na videz nepomembno izkušnjo preko refleksije spremenimo v znanje, ki je rezultat transakcije med družbenim in osebnim znanjem v procesu učenja.

Več izkušenj kot imamo, bolj prožno je naše razmišljanje in lažje je iskanje ter razumevanje povezav/soodvisnosti med naravno in družbeno geografskimi pojavi/dejavniki.

Izkustveno učenje ustvarja reprezentativno učno okolje, kar pa naredi geografsko izobraževanje bolj relevantno. Tesneje preplete teorijo s prakso in s tem pripomore $\mathrm{k}$ razvijanju lastnosti, ki bodo ljudem potrebne v prihodnji t. i. informacijski ali postindustrijski družbi. Te so: sposobnost prožnega prilagajanja na nove okoliščine, osebna avtonomija, sposobnost komunikacije in sodelovanja, zmožnost celovitega dojemanja, integracije, sinteze, analize ... (Požarnik 1992, 1-3). 
Sposobnost oblikovanja analize, sinteze in integracije so cilji, ki so v Bloomovi taksonomiji postavljeni najvišje in jih je najtežje doseči, vendar so pri tako močno sintezni vedi, kot je geografija, neobhodni.

Vemo, da teh kompleksnih ciljev ne dosežejo vsi dijaki. Vendar naj bi vsako kvalitetno učno okolje povezovalo dimenzije dojemanja, razumevanja, intenzije ter ekstezije.

Pri izkustvenem učenju se vse začne z izkušnjo, tej sledi opazovanje in analiza, nato vključitev v slovar abstraktnih pojmov in preizkušanje v novi situaciji. Vendar ljudje dajejo različne poudarke posameznim dimenzijam. Kolb je glede na poudarek na posameznem polu spoznavanja oblikoval štiri učne stile:

- $\quad$ akomodativni učni stil poudarja konkretno izkušnjo in aktivno preizkušanje idej. Ljudje s tem učnim stilom so uspešni pri izpeljavah načrtov v konkretnih situacijah, kjer se je potrebno stalno prilagajati spreminjajočim se okoliščiam. Od tod izvira tudi naziv akomodativnost. Probleme rešujejo po principu poskusov in napak;

- divergentni učni stil kombinira konkretne izkušnje in razmišljajoče opazovanje. Človek s tem učnim stilom situacije preuči z vseh zornih kotov. Odnose zna povezovati med seboj v smiselno-logično celoto. Ljudje tega tipa se dobro znajdejo v popolnoma novih situacijah, ki terjajo od njih ustvarjanje do sedaj nepoznanih/neodkritih idej;

- konvergentni učni stil se opira na abstraktno razmišljanje in aktivno eksperimentiranje. Ti ljudje so uspešni pri reševanju zaprtih problemov oz. problemov z enim samim pravilnim/najboljšim odgovorom oz. rešitvijo. Dobljene rezultate preizkušajo;

- $\quad$ asimilativni učni stil gradi na abstraktnem razmišljanju in razmišljajočem opazovanju. Njegova odlika je induktivno sklepanje, ki vodi do oblikovanja teorije/modela. Ljudi asimilativnega tipa ne zanima praktična uporabnost njihovih izsledkov. Svoje ideje presojajo le iz vidika logočnosti in točnosti (Sternberg in Grigorenko, 2001, 1-23).

Kolb je zgradil model učnih stilov na svojem pojmovanju procesa izkustvenega učenja, ki je nastal kot reakcija na nepovezanost med teorijo in prakso in zanemarjanje posameznikove izkušnje v vzgojno-izobraževalnem procesu (Marentič-Požarnik, 1994, str. 477) in s tem siromašenju samega učnega okolja.

Po zastareli teoriji je učenje proces kopičenja znanja, princip seštevanja/adicije. To pomeni, da je najvišji produkt tega učenja kopičenje informacij. Na tem aditivnem oz. seštevalnem pojmovanju učenja temelji »transmisijsko« pojmovanje pouka (Marentič-Požarnik 1991, 580). Izkušnje učencev so $\mathrm{v}$ tem procesu nepomembne.

Iz tega sledi, da izkustveno učenje zanika aditivno pojmovanje učenja in »transmisijsko« pojmovanje pouka. »Trdi, da se vsako spoznanje (ideja, pojem, teorija ...) preoblikuje v stiku z osebno izkušnjo in da je vsako novo znanje rezultat take rekonstrukcije« (MarentičPožarnik 1992, 4). To je transformacijsko pojmovanje pouka. Izkušnja, ki ima središčno vlogo v procesu učenja.

Ob upoštevanju Kolbovih učnih stilov in pojma izkustvenega učenja moramo nujno spremeniti pogled na »klasično« pojmovanje znanja, učenja in učnega okolja. Narediti moramo prehod od transmisijskega $\mathrm{k}$ transformacijskemu učenju in poučevanju ter s tem ustvariti spodbudno geografsko učno okolje. 


\section{PRVI DEL RAZISKOVALNEGA DELA}

\section{I Namen in metodologija}

Namen raziskave je bil spoznati učne stile dijakov drugih letnikov gimnazijskih programov, ter ugotoviti ali dijaki pri geografiji uporabljajo metode, ki najbolj ustrezajo posameznim učnim stilom (raziskovalno vprašanje).

Postavili smo naslednje hipoteze:

- $\quad$ stopnja srednje šole vpliva na učni stil pri predmetu geografija;

- učni stil vpliva na uspešnost pri geografiji;

- ni povezave med učnim stilom in spolom pri predmetu geografija.

Pri delu smo uporabili več metod. Te so: deskriptivna metoda, kavzalno-neeksperimentalna metoda, kvantitativna metoda. Uporabljene tehnike so bile: ankentiranje, kvantitativna analiza podatkov, instrumenti pa: Kolbov vprašalnik o učnih stilih (priredila Barica Marentič Požarnik) in statistični izračuni.

V raziskavo (vzorec) je bilo zajetih 293 dijakov drugih letnikov srednjih šol z gimnazijskim programom. Način vzorčenja je neslučajnosten. Sam vzorec je priložnostni. Značilnosti vzorca so podane $\mathrm{v}$ preglednici.

Preglednica 1: Predstavitev vzorca glede na strukturo spola, števila in starosti (Nemec 2004, 32)

Table 1: Presentation of sample in view of sex, number and age structure (Nemec 2004, 32)

\begin{tabular}{|l|c|c|c|c|c|c|}
\hline \multirow{2}{*}{ Srednja šola } & \multirow{2}{*}{ Število } & \multicolumn{2}{|c|}{ Spol } & \multicolumn{3}{c|}{ Starost (v letih) } \\
\cline { 3 - 7 } & & ženski & moški & $\mathbf{1 5}$ & $\mathbf{1 6}$ & $\mathbf{1 7}$ \\
\hline Splošna gimnazija & 56 & 36 & 20 & $/$ & 48 & 8 \\
\hline Jezikovna gimnazija & 28 & 22 & 6 & $/$ & 21 & 7 \\
\hline Klasična gimnazija & 51 & 38 & 13 & 2 & 44 & 5 \\
\hline Ekonomska gimnazija & 53 & 30 & 23 & $/$ & 41 & 12 \\
\hline Tehniška gimnazija & 59 & 26 & 33 & 3 & 35 & 21 \\
\hline SŠ za elektroniko in računalništvo & 46 & 0 & 46 & $/$ & 36 & 10 \\
\hline \multirow{2}{*}{ Skupaj } & 293 & 152 & 141 & 5 & 225 & 63 \\
\cline { 3 - 7 } & & \multicolumn{2}{|c|}{293} & & 293 & \\
\hline
\end{tabular}

V času raziskave, ki je potekala od 12 . do 31 . marca 2004 , je bilo $1,5 \%$ dijakov starih 15 let, $76,8 \%$ starih 16 let in $21,5 \%$ starih 17 let. V raziskavo je bilo zajetih $51.9 \%$ deklet in $48.1 \%$ fantov. Od sodelujočih v raziskavi jih je prihajalo $19,2 \%$ iz splošne gimnazije, 9,6 \% iz jezikovne gimnazije, 17,4 \% iz klasične gimnazije, 18,1 \% iz ekonomske gimnazije, 20,1\% iz tehniške gimnazije in $15,7 \%$ iz SŠ za elektroniko in računalništvo. 
Za ankete je bil uporabljen Kolbov vprašalnik o učnih stilih (priredila Barica Marentič Požarnik), katerega sem dopolnila z vprašanji o spolu, starosti, šoli in oceni iz geografije v prejšnjem šolskem letu. Pri statistični obdelavi podatkov anket so bili izračunani naslednji podatki: \% deleži odgovorov, $\chi^{2}$ preizkus.

\subsection{Rezultati in interpretacija}

\section{1. hipoteza: stopnja srednje šole vpliva na učni stil pri predmetu geografija.}

Učni stili posameznika se oblikujejo v stalni interakciji naslednjih dejavnikov:

- osebnostnih potez (npr. introvertiranost, ekstravertnost, ...),

- zgodnjih izkušenj,

- $\quad$ izkušenj v času šolanja (Marentič-Požarnik 1995, 86).

Kolb (Kolb 1984, 86) je ugotovil, da je najpomembnejši dejavnik pri oblikovanju učnega stila prav šolska specializacija, ki se začne z izbiro srednje šole in nadaljuje z izbiro visokošolskega študija. Njegove raziskave učnih stilov študentov različnih fakultet so to tezo potrdile. Na podlagi tega je oblikoval shemo razporeditve pripadnikov različnih disciplin in poklicev po prostoru učnih stilov. Iz zgoraj navedenih razlogov sem postavila hipotezo, da stopnja srednje šole vpliva na učni stil pri pouku geografije.

Graf 1: Učni stili glede na tip srednje šole (Nemec 2004, 60)

Chart 1: Learning-styles in view of type of secundary scholl (Nemec 2004, 60)

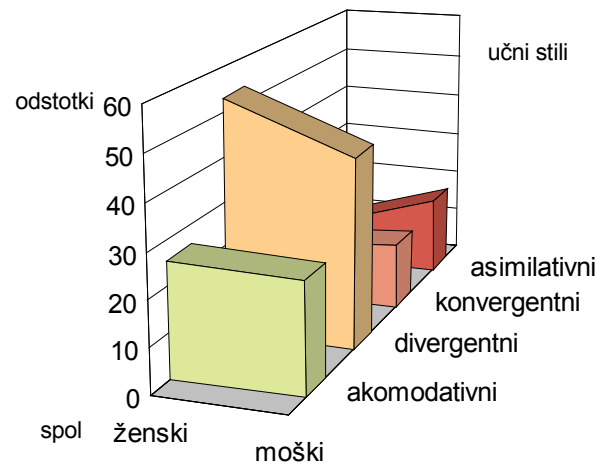

Hipoteza je na osnovi analize vseh zbranih podatkov zavrnjena. Stopnja srednje šole tako ne vpliva na učni stil pri predmetu geografija $\left(\chi^{2}=5,23 ; p=0,05\right)$. Divergentni učni stil namreč prevladuje na vseh šolah (splošna gimnazija 48,2\%, klasična gimnazija 58,8\%, ekonomska gimnazija 56,6\%, tehniška gimnazija 42,4\%, srednja šola za računalništvo in elektroniko 41,3\%). Izjema je le jezikovna gimnazija s prevladujočim akomodativnim učnim stilom (46,4\%). Vzrok za zavrnitev korelacije med vrsto srednje šole in učnim stilom lahko pripišemo še neizrazitemu vplivu šolske specializacije v drugem letniku srednje šole. 
Prevladujoč divergentni stil pri geografiji pa istočasno nakazuje, da učitelji pri pouku geografije vse bolj razvijajo didaktične pristope, se orientirajo po didaktičnih načelih, uporabljajo vse širšo paleto učnih oblik in metod oz. $\mathrm{z}$ eno besedo ustvarjajo vse bolj spodbudna učna okolja, ki omogočajo sodelovalno učenje in premik od transmisijskega k transformativnem učenju in poučevanju. Nizka zastopanost konvergentnega učnega stila, ki poudarja pomen transmisijskega učenja, ta premik še bolj potrjuje.

Rezultate o učnih stilih bi lahko izkoristili npr. pri pisanju učbenikov, kjer bi način podajanja snovi prilagodili učnim stilom dijakov. Prednost pri tem bi bila, da bi en učbenik pravzaprav ustrezal vsem šolam hkrati, kajti kot smo ugotovili, šolske specializacije še ni, pri geografiji pa imamo 48,1 \% divergentnežev in 25,3 \% akomodativcev.

\section{2. hipoteza: učni stil vpliva na uspešnost pri geografiji.}

$\chi^{2}$ preizkus je pokazal, da korelacije med učnim stilom in uspešnostjo pri geografiji na izbranem vzorcu ni $\left(\chi^{2}=5.23 ; p=0,05\right)$. Postavljena hipoteza je torej zavrnjena.

Kljub zavrnitvi korelacije se kažejo posamezne povezave med učnim stilom in uspešnostjo dijakov pri geografiji. Po Kolbovih rezultatih naj bi pri geografih prevladoval asimilativni učni stil. Tako ima oceno odlično pri geografiji največ dijakov z asimilativnim učnim stilom v splošni gimnaziji (40\%) in jezikovni gimnaziji (50\%).

Prav dobro oceno imajo največkrat dijaki s konvergentnim učnim stilom (jezikovna gimnazija 66,7\%) ali akomodativnim učnim stilom (splošna gimnazija 58,3\%, klasična gimnazija 50\%). Konvergentni učni stil ima $\mathrm{z}$ asimilativnim/ »geografskim« učnim stilom skupno komponento abstraktne konceptualizacije. Mogoče je to razlog za visoko uspešnost dijakov konvergentnega stila pri geografiji.

Oceno tri imajo dijaki vseh učnih stilov, tako da sovpadanja med učnim stilom in uspešnostjo na tem primeru ne moremo dokazati.

Graf 2: Učni stili in uspeh pri geografiji (Nemec 2004, 62)

Chart 2: Learning-styles and success in geography (Nemec 2004, 62)

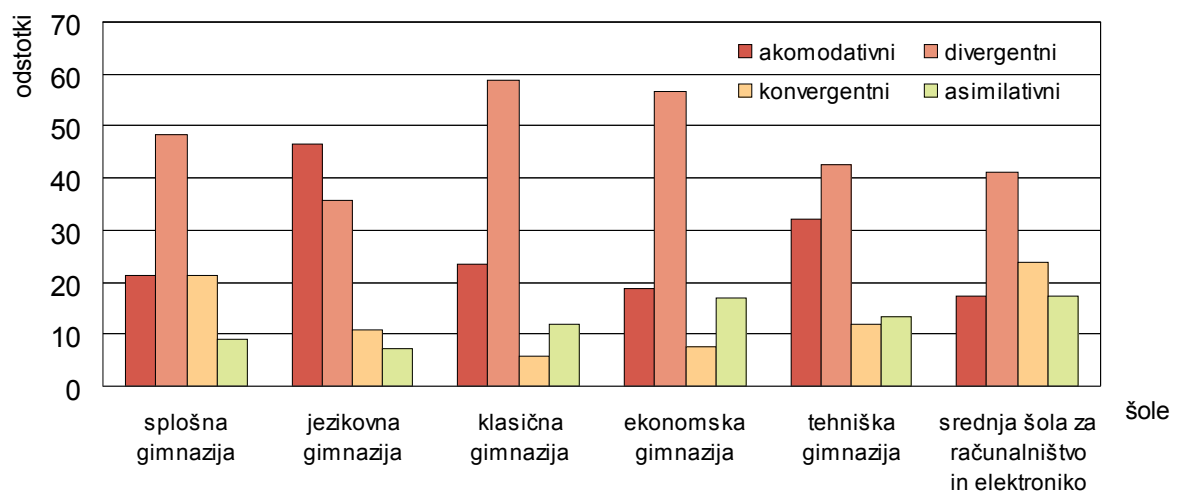




\section{3. hipoteza: pri predmetu geografija ni povezave med učnim stilom in spolom.}

Analiza zbranih podatkov hipotezo potrjuje $\left(\chi^{2}=0,713 ; p=0,05\right)$. To pomeni, da je učni stil popolnoma neodvisen od spola. Zato v nobenem primeru ne bi mogli reči, da je posamezni učni stil tipičen npr. za dijakinje.

Največja razlika med deležema spolne zastopanosti je pri asimilativnem oz. t.i. »geografskem « učnem stilu. Asimilativni stil ima 17,7 \% vseh dijakov in 8,6 \% dijakinj. Prevladujoč delež pri tem stilu imajo dijaki na vseh izbranih šolah, v jezikovni gimnaziji celo 100 odstoten. Izjema je le klasična gimnazija, kjer ima asimilativni učni stil več učenk (66,7 \%). Iz tega bi lahko sklepali, da je v večini primerov geografski način razmišljanja malo bližje dijakom kot dijakinjam, kar se kaže tudi v njihovi večji uspešnosti.

Graf 3: Učni stili in spol pri geografiji (Nemec 2004, 63)

Chart 3: Learning-styles and sex in geography (Nemec 2004, 63)

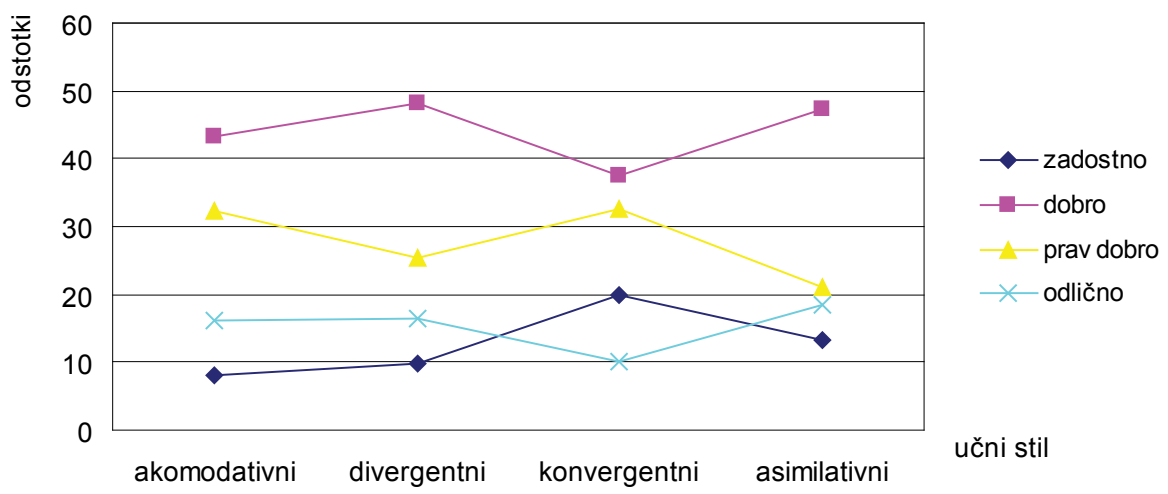

\section{Raziskovalno vprašanje: ali dijaki pri geografiji uporabljajo metode, ki najbolj ustrezajo posameznim učnim stilom.}

Rezultati raziskav kažejo, da dijaki z akomodativnim in divergentnim učnim stilom pri učenju uporabljajo metode, ki najbolj ustrezajo njihovemu učnemu stilu. Za prve so to metode D (študije primerov, simulacije, praktično delo), katere je izbralo 33,8\% dijakov, medtem ko metode A (igre vlog, »možganska nevihta«, trening senzitivnosti) uporablja 36,9\% dijakov z divergentnim učnim stilom. Posledica pravilne izbire učnih metod s strani dijakov z akomodativnim učnim stilom je njihova visoka uspešnost pri geografiji. 32,5\% vseh akomodativcev ima prav dobro oceno pri geografiji.

Konvergentneži se delno (20\%) poslužujejo njim najbolj ustreznih metod B (uporaba teoretičnih znanj, pravil in postopkov pri reševanju nalog in problemov z razmeroma enoznačno rešitvijo). Posledica nepravilne izbire metod se kaže tudi v slabšem uspehu pri geografiji. Zadostno oceno imajo največkrat dijaki s konvergentnim učnim stilom (jezikovna gimnazija 33 \%, ekonomska gimnazija 50 \%, srednja šola za računalništvo in elektroniko). 
Učencem asimilativnega učnega stila naj bi bile najbližje metode tipa $\mathrm{C}$ (sistematično zastavljena predavanja in poglobljen študij literature, primerjava izhodišč različnih avtorjev, ki vodi do izgradnje teoretičnih modelov), vendar jih uporablja le 10,5\% dijakov, medtem se ko 34,2 \% dijakov poslužuje metod D. Zanimivo je dejstvo, da kljub temu, da ne uporabljajo "pravih« metod, so pri geografiji eni najbolj uspešnih. Največji delež odličnih ocen odpade prav na njih. Tako ima oceno odlično pri geografiji 47,5 \% dijakov z asimilativnim učnim stilom.

Graf 4: Učne metode in učni stili pri geografiji (Nemec 2004, 64)

Chart 4: Learning methods and learning-styles in geography (Nemec 2004, 64)

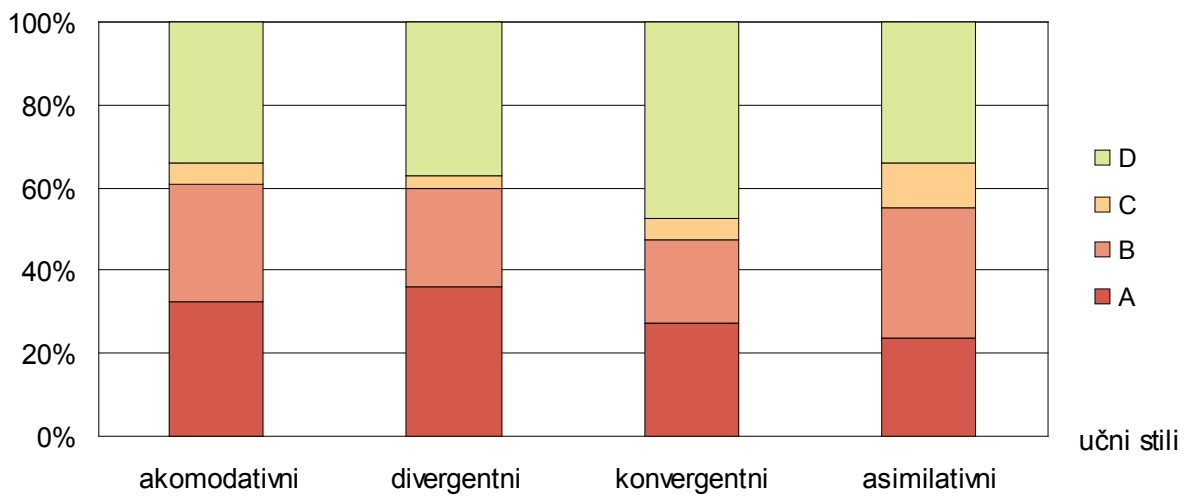

A - metode, ki dopuščajo in celo terjajo različne poti, odgovore, reakcije ter obenem usmerjenost vosebno, neponovljivo doživljanje: skupinska dinamika, trening senzitivnosti, igre vlog, »možganska nevihta«.

B - situacije, ki terjajo neposredno uporabo teoretičnih znanj, pravil, postopkov pri reševanju nalog in problemov z razmeroma enoznačno rešitvijo.

C - sistematično zastavljena predavanja in poglobljen študij literature, primerjava izhodišč različnih avtorjev, ki vodi do izgradnje teoretičnih modelov.

$D$ - metode, pri katerih je treba aplicirati naučeno na reševanje (simuliranih ali resničnih) praktičnih problemov, ob povezavi najrazličnejših spoznanj in upoštevanju vsakokratnih okoliščin: študije primerov, simulacije, menjavanje obdobij prakse in študija, terenske izkušnje.

\section{DRUGI DEL RAZISKOVALNEGA DELA}

\section{I Namen in metodologija}

Učitelji geografije pri strukturiranju učne ure najbolj upoštevajo učno snov in cilje. Šele na tretjem mestu so učenci oz. njihove potrebe, zanimanja (Resnik Planinc 2000, 130). »Učenec je tisti, zaradi katerega je pouk organiziran,« je zapisala Tomićeva $(1997,33)$, torej bi moralo biti razmerje med snovjo, učnimi cilji in potrebami učenca enakovredno, če bi želeli ustvariti spodbudno učno okolje. 
Vendar ne le da učitelji ne upoštevajo učenca pri izbiri metod, niti učenci sami ne poznajo metod, ki so njihovemu učnemu stilu najbližje. Tako ne preseneča dejstvo, da 56,9 \% učiteljev pri poučevanju uporablja verbalno-tekstualne metode (metode ustnega razlaganja, metode pogovora) (Resnik Planinc 2001, 130), medtem ko bi 48,1 \% učencem glede na njihov učni stil najbolj ustrezale metode izkustvenega učenja (brainstorming, skupinska dinamika, igre vlog, trening senzitivnosti) (Nemec, 2004, 69).

Učitelji geografije se v 54,9 \% poslužujejo frontalne učne oblike (Resnik Planinc 2000, 130), vendar pa bi 73,4 \% dijakom, glede na njihov učni stil, najbolj ustrezala skupinska učna oblika oz. delo v parih (Nemec 2004, 75). Slednjo učitelji uporabljajo le v 29,2 \% primerov (Resnik Planinc 2000, 130). Zaključek je torej ta, da izbor metod in oblik s strani učitelja ni v skladu z željami in pričakovanji učencev (Resnik Planinc 2000; Resnik Planinc 2006; Nemec 2004).

Pri ustvarjanju produktivnega učnega okolja sta cilj in snov pomembna dejavnika pri izbiri učnih metod, vendar sta oba neločljivo povezana z učencem. Uspešnost pri geografiji bomo povečali le, če bomo pri izbiri metod in oblik bolj upoštevali potrebe/interese posameznika/učenca. Slednje lahko storimo s poznavanjem učnih stilov učencev.

Namen drugega dela raziskave je nadgradnja predstavljenih rezultatov s praktičnim preizkusom. S poskusom didaktičnega eksperimenta smo preverili uporabo pristopov (izbor učnih metod, oblik) izkustvenega učenja pri pouku geografije.

Postavili smo naslednje hipoteze:

- dijaki, ki bodo delali po pristopu izkustvenega učenja, bodo dosegli boljše rezultate kot dijaki, ki bodo delali po starem, »tradicionalnem《 pristopu,

- dijaki, ki bodo delali po pristopu izkustvenega učenja, bodo pri vprašanjih višjega nivoja dosegali boljše rezultate kot dijaki, ki bodo delali po starem, »tradicionalnem pristopu.

Pri delu smo uporabili več metod: deskriptivna metoda, kavzalno-neeksperimentalna metoda, kvantitativna metoda. Uporabljene tehnike so bile: kvantitativna analiza podatkov, instrumenti pa: preizkus znanja, statistični izračuni (t-test, povprečja).

$\mathrm{V}$ eksperimentu sta sodelovala dva razreda drugega letnika Ekonomske gimnazije. Prvi razred (27 učencev) je obravnaval učno vsebino (učna enota: Mehika) po pristopu izkustvenega učenja, drugi razred (23 učencev) pa po klasičnemu, »tradicionalnem « pristopu. Po izvedbi obeh ur je sledilo 10-minutno testiranje v obliki testa, seveda na temo učne enote. Test je sestavljalo 6 vprašanj. Vsako vprašanje je pokrivalo eno stopnjo kognitivnega področja po Bloomovi taksonomiji.

\subsection{Rezultati in interpretacija}

\section{1. hipoteza: dijaki, ki bodo delali po pristopu izkustvenega učenja, bodo dosegli boljše rezultate kot dijaki, ki bodo delali po starem, »tradicionalnem《 pristopu.}

Dijaki, ki so delali po pristopu izkustvenega učenja, so dosegli boljše rezultate pri preizkusu znanja (povprečno število doseženih točk 17,8) kot dijaki, ki so delali po tradicionalnem pristopu (povprečno število doseženih točk 14,9). Razlike na področju doseženih točk obstajajo, vendar niso statistično pomembne $(\mathrm{t}=0,890 ; \mathrm{t} 0,5(48)=2.05)$. Hipoteze ne moremo potrditi. 
Na tem mestu bi poudarila, da smo izvedli enkratni poskus didaktičnega eksperimenta. Prepričani smo, da bi se, ob večjem vzorcu, večkratnem ponavljanju/seznanitvi učencev z izkustvenim učenjem in s tem odpravi vpliva najrazličnejših zunanjih dejavnikov, razlike pokazale tudi za statistično pomembne.

\section{2. hipoteza: učenci, ki bodo delali po pristopu izkustvenega učenja, bodo pri vpra- šanjih višjega nivoja (4,5,6 vprašanje) dosegali boljše rezultate kot dijaki, ki bodo delali po starem, »tradicionalnem« pristopu.}

Učenci, ki so delali po principu izkustvenega učenja, so pri vprašanjih višjega nivoja dosegli boljše rezultate (povprečno število doseženih točk 7,6) kot dijaki, ki so delali po tradicionalnem pristopu (povprečno število doseženih točk 6,1). 70,9 \% dijakov, ki so bili deležni pristopa izkustvenega učenja, je pravilno odgovorilo na vsa vprašanja višjega nivoja. To je uspelo le 58,1 \% dijakom, katerim je bila snov prikazana preko »tradicionalnega« pristopa. Razlike na področju točk obstajajo, vendar niso statistično pomembne (t-test). Razlogi za tak rezultat so enaki zgoraj navedenim.

\section{ZAKLJUČEK}

Sinteza zaključkov raziskovalnega dela daje naslednje ugotovitve:

- $\quad$ stopnja srednje šole ne vpliva na učni stil pri predmetu geografija;

- $\quad$ učni stil ne vpliva na uspešnost pri geografiji;

- $\quad$ pri predmetu geografija ni povezave med učnim stilom in spolom;

- dijaki z akomodativnim in divergentnim učnim stilom pri geografiji uporabljajo metode, ki najbolj ustrezajo njihovemu učnemu stilu;

- $\quad$ dijaki, ki so delali po pristopu izkustvenega učenja, so dosegli boljše rezultate kot dijaki, ki so delali po starem, »tradicionalnem« pristopu, vendar razlike niso statistično pomembne;

- $\quad$ dijaki, ki so delali po pristopu izkustvenega učenja, so pri vprašanjih višjega nivoja dosegli boljše rezultate kot dijaki, ki so delali po starem, »tradicionalnem pristopu«, vendar razlike niso statistično pomembne.

Ob uresničitvi zastavljenih ciljev so se odprla nova vprašanja, dileme in naloge. V prihodnosti bi bilo tako smiselno nadaljevati z raziskovalnim delom na področju šolske geografije v smislu:

- $\quad$ usposabljanja učiteljev (preko tečajev in seminarjev) za ustrezen izbor učnih oblik in metod glede na učne stile učencev v razredih;

- $\quad$ stalnega strokovnega izpopolnjevanja učiteljev geografije;

- "prilagajanja« učbenikov učnim stilom dijakov;

- $\quad$ raziskovanja učinkov uporabe izkustvenega učenja pri pouku geografije;

- $\quad$ seznanjanja dijakov z njihovimi učnimi stili ter njim najbolj ustreznimi metodami za učenje.

Le $\mathrm{z}$ aktivnim raziskovanjem učnih stilov bomo resnično spoznali njihove učinke, ne le v učnem okolju, temveč tudi v našem življenjskem prostoru. Glede na dejstvo, da 
le dijaki z akomodativnim in divergentnim učnim stilom uporabljajo metode, ki najbolj ustrezajo njihovemu učnemu stilu, si lahko le zamislimo, kakšen bi bil šele učinek, če bi vsi dijaki poznali svoje učne stile in tudi temu primerno izbirali učne metode. V praksi pa bi to najbolj koristilo dijakom z učnimi problemi, saj geografija izkazuje visok odstotek zahtevnih učnih vsebin. Če pa bi učitelji poznavanje in uporabo učnih stilov pri pouku nadgradili z izkustvenim učenjem, učenjem, ki izhaja iz kompleksnosti izkušenj iz vseh področij dijakovega/človekovega delovanja, bi ustvarili produktivno učno okolje, takšno, ki izhaja iz potreb samega učenca. Rezultat takšnega izobraževanja bi bil človek, ki bi se znal identificirati z okoljem in bi do njega razvil tudi odgovoren odnos na vseh nivojih bivanja.

\section{Viri in literatura}

Gregorenko, E. L., Sternberg, R. J., 2001. A capsule history of theory and research on styles. $\mathrm{V}$ : Perspectives on thinking learning and cognitive styles. London, Erlbaum Assciates, str. 1-23.

Kolb, D. A., 1984. Experiential learning. Experience as the source of learning and development. , Englewood Cliffs, Prentice Hall, 255 str.

Medmrežje 1: www.pei.si/czue (12.2.2008).

Ehlers, U., D., 2007. The E-emploering learners:myths and realities in learner orientated elearning quality. Medmrežje: http:// www.elearningpapers.eu. (12.2.2008).

Marentič Požarnik, B., 1991. Pomen operativnega oblikovanja vzgojnoizobraževalnih smotrov za uspešnejši pouk. Novo mesto, Pedagoška obzorja, str. 5-80.

Marentič Požarnik, B., 1992. Izkustveno učenje - modna muha, skupek tehnik ali alternativni model pomembnega učenja? Sodobna pedagogika, 43, 1-2, str. 1-15

Marentič Požarnik, B., 1994. Učni stili - ključ za razumevanje pomembnih medsebojnih razlik v učenju in poučevanju (1. del: Kolb). Sodobna pedagogika, 45, 9-10, str. 473490.

Marentič Požarnik, B., 1995. Učni stili po Kolbu. V: Izziv raznolikosti. Nova Gorica, Educa, str. 76-105.

Nemec, L., 2004. Didaktični pristopi k poučevanju geografije v srednjih šolah z vidika učnih stilov, oblik in metod. Diplomsko delo. 157 str.

Resnik Planinc, T., 2001. Zahtevnejše geografske vsebine kot izobraževalni problem. Doktorska disertacija. 248 str.

Resnik Planinc, T., 2006. Vrednote prostora kot integralni del izobraževanja. Geografski vestnik. 76-2, str. 9-24.

Smrekar, A., 2006. Zavest ljudi o pitni vodi. Geografija Slovenije 12. Ljubljana.

Tomić, A., 1997. Izbrana poglavja iz didaktike. Ljubljana, Filozofska fakulteta, Center za pedagoško izobraževanje, 181 str.

Vrišer, I., 1998. Uvod v geografijo. 6. izd. Ljubljana, Filozofska fakulteta, Oddelek za geografijo, str. 5

Zlatkovski, S., 2005. Vizija prostora popotnika. Medmrežje: http://www.ish.si/ ljsh8/files/ PDF2005-2006 (12.2.2008) 


\title{
CREATING THE PRODUCTIVE GEOGRAPHICAL LEARNING ENVIRONMENT FROM THE POINT OF VIEW OF LEARNING- STYLES AND LEARNING-METHODS
}

\begin{abstract}
Summary
Experiences, which we receive in space (in)directly influence on education process respectively on learning-environment. Because of that is the most productive learningenvironment those witch founded on experiential-learning. In this research experience took the leading place in forming didactical approaches in teaching geography and to define learning-styles and methods respectively in the direction of creating representative geographical learning-environment.

Kolb's studying-styles (accommodative, divergent, assimilative, convergent learning style), that represent the core of this thesis, stand for ways of acquiring information, concept and skills based on experimental learning, the latter being a process where knowledge is formed with the transfer of experiences into an abstract concept.

With questionnaires, knowledge test and the trial didactical experiment, all carried out in $2^{\text {nd }}$-year college classes, I came to the next conclusions:

- the type of school does not have an impact on the pupils learning style;

- learning style does not effect on successfulness at geography;

- $\quad$ the learning styles are independent from the pupils sex;

- $\quad$ in geography pupils with accommodative and divergent learning style using methods which are the most appropriate to their learning style;

- teachers do not adapt their learning-methods to pupils needs;

- the trial didactical experiment based on experimental-learning, confirmed a rise in the pupils level of knowledge (Bloom' classification of learning aims) in the case where learning-methods were adapted to the pupils one, but the t-test showed that differences between group which work on traditional approach (frontal accession) and group which work on experimental learning are not statistical important.

Only with active research of learning-styles we will know their effects, not only in the learning environment, but also in our living space. From the leaving space we take the experiences which are driving force of experience learning. Because of increasing a many-sides experience from all field of work is today necessary, that in process of creating productive learning environment we result from pupils needs. Because of that is important to consider the pupils learning style for choosing learning methods, learning approaches in geography in general.
\end{abstract}

